University of Nebraska - Lincoln

DigitalCommons@University of Nebraska - Lincoln

1987

\title{
ALCOHOLS AS COMPONENTS OF TRANSPORTATION FUELS
}

G. Alex Mills

E. Eugene Ecklund

Follow this and additional works at: https://digitalcommons.unl.edu/usdoepub

This Article is brought to you for free and open access by the U.S. Department of Energy at

DigitalCommons@University of Nebraska - Lincoln. It has been accepted for inclusion in US Department of Energy Publications by an authorized administrator of DigitalCommons@University of Nebraska - Lincoln. 


\section{ALCOHOLS AS COMPONENTS OF TRANSPORTATION FUELS ${ }^{1}$}

\section{G. Alex Mills}

Center for Catalytic Science and Technology, Department of Chemical Engineering, University of Delaware, Newark, Delaware 19716

\section{E. Eugene Ecklund}

Engine Technology Programs, Office of Transportation Systems, Conservation and Renewable Energy, US Department of Energy, Washington, D.C. 20585

\section{ALCOHOLS-THE "NEW" FUELS}

Alcohols have the potential to revolutionize energy fuel supply and use, particularly in transportation. This worldwide potential is based on $(a)$ the variety of widely available raw materials from which alcohols can be made (coal, natural gas, petroleum, and biomass), (b) the improved and demonstrated technology for alcohol manufacture and use, and $(c)$ the favorable combustion characteristics of alcohols, namely clean burning with high octane performance.

The barriers to widespread use of alcohols as fuels are their current relatively high cost compared to petroleum (which cost about $\$ 15 /$ barrel in 1986), lack of an established distribution system, concerns about health protection, and engine considerations. Only minor engine modifications are needed for alcohol-gasoline blends, but use of neat (100\%) or near-neat alcohol would require extensive ones. However, especially for the longer term, neat alcohols can have advantages in higher thermal efficiency (more miles per Btu), achievable through the use of lean combustion and higher compression engines than those presently used for gasoline.

Alcohols have advantages in special circumstances even at present. Examples include ethanol from sugarcane in Brazil and octane-enhancing ethanol or methanol added to gasoline in the United States and Europe. However, the longer-term prospects (indeed requirements) for alcohol synthetic fuels are

\footnotetext{
'The US Government has the right to retain a nonexclusive, royalty-free license in and to any copyright covcring this paper.
} 
most significant, along with the present actions necessary to prepare to meet these requirements.

Alcohol fuels have long been known in home and industry. Best known is grain alcohol or ethanol, $\mathrm{C}_{2} \mathrm{H}_{5} \mathrm{OH}$, manuf actured since antiquity by fermentation. Another familiar alcohol is methanol or wood alcohol, $\mathrm{CH}_{3} \mathrm{OH}$, so named since it was originally produced as a by-product in the destructive distillation of wood to produce charcoal. A third alcohol, also in household use, is rubbing alcohol, known chemically as isopropanol, $\mathrm{C}_{3} \mathrm{H}_{7} \mathrm{OH}$. A fourth alcohol is tertiary butanol, $\mathrm{C}_{4} \mathrm{H}_{9} \mathrm{OH}$, produced in plastics manufacture. It is these alcohols, especially methanol and ethanol, but also mixtures containing the higher alcohols, which act as cosolvent for methanol in gasoline blends, that present such favorable opportunities as components of transportation fuels. Though not an alcohol, methyl tertiary butyl ether (MTBE), made from methanol and isobutene, is also widely used in gasoline blends.

The quantities of materials used as energy fuels far exceed those used as industrial chemicals. Methanol is one of the organic chemicals manufactured in largest quantity, with US production of 10,000 tons, or 70,000 barrels, per day (BPD). Gasoline usage, in comparison, is 6,500,000 BPD. Moreover, gasoline has twice the heating value of methanol per gallon.

Methanol and ethanol each have a density of 0.79 . There are seven barrels of alcohol per ton. Each 42-gallon barrel weighs 277 pounds, each gallon 6.6 pounds.

The production of 1 million BPD of methanol would supply about $7 \%$ of the transportation sector's current gasoline needs (on an energy-equivalent basis) and would require about 250,000 tons of coal or about 4700 million cubic feet of pipeline gas per day. These amounts correspond to about one tenth the daily production of coal or of gas in the United States. Thus, the establishment of a methanol fuel industry to supply the blend market or provide initial penetration of the neat alcohol market would not require an unreasonable increment in coal or gas production spread over a period of years (1).

To produce 1 million BPD of ethanol, corresponding on an energy basis to about $10 \%$ of gasoline usage in the United States, would require 6 billion bushels of com. However, the annual total US corn crop is only 4.5 billion bushels (1). Use of additional land to produce this much grain for alcohol fuel would have serious environmental impacts.

Interwoven in the fabric of concern about alcohol fuels are critical nontechnical issues, such as changes in employment sectors, the balance of trade, tax policies, and social questions such as the possibility of competition for grain between food and fuel.

Alcohols have been reviewed previously in the Annual Review of Energy $(2-4)$. In addition, several recent books focus on alcohol fuels $(5,6)$, which 
have been the subject of seven international symposia (7), a newsletter (8), and chapters in books on synthetic fuels $(1,9,10)$ and coal technology $(11$, 12). There has also been an enormous proliferation of scientific papers on catalysis of syngas reaction, with the aim of understanding and controlling alcohol synthesis.

\section{CHANGING USE PATTERNS AND METHODS OF MANUFACTURE}

The uses of alcohols have determined the amounts required and the development of appropriate technology.

Ethanol is made synthetically by ethylene hydration, or by fermentation of corn in the United States and sugarcane in Brazil. The economics of producing ethanol favor ethylene hydration, but a federal tax credit of $6 \phi /$ gallon of gasohol-equivalent to $60 \propto /$ gallon of US-produced fermentation ethanollowers the net cost of corn-based ethanol for fuel use.

Ethanol was used in automobiles in the early part of the century until low-cost gasoline forced it off the market. Alcohols have also been used during shortages of petroleum. Racing cars often use methanol fuel because, among other reasons, of the increase in power that can be obtained compared to a similar gasoline-fueled engine.

Methanol was used for lighting, beginning about 1830, later being replaced by whale oil. In turn, it was replaced by more luminous kerosene in the $1880 \mathrm{~s}$. Some use of methanol for cooking and heating continued. With the advent of the chemical industry, and particularly plastics manufacture, beginning in the 1920s methanol again became important, this time as a chemical intermediate. The large-scale use of methanol as a fuel promises unprecedented levels of production and use.

The recent use of methanol as a transportation fuel in the United States was prompted by the petroleum shortage of the 1970s, beginning with reports drawing attention to the opportunities for methanol fuels $(13,14)$ and gradually increasing commercial introduction into gasoline blends. Recently, greater recognition has been given to the octane-enhancing values of alcohols in gasoline blends, especially with the phase-down of lead in gasoline.

The first plant to synthesize methanol from synthesis gas, a mixture of hydrogen, carbon monoxide, and carbon dioxide, began operation in Germany in 1923. Initially synthesis gas was made from coal, but since World War II low-cost natural gas and light petroleum distillates have almost completely displaced coal. During this period, individual plant capacities have grown from 40 tons per day (tpd) in the 1930s to 2000 tpd in the 1970s. A recently constructed plant in New Zealand has a production capacity of 4200 tpd in two units. Saudi Basic Industries has two units capable of making 
3750 tpd. Methanol production has grown in the United States from 1960 tpd in 1955 to 3900 tpd in 1965, 7200 tpd in 1975, and 8200 tpd in 1985 (down from 11,200 tpd in 1984).

\section{USE AS TRANSPORTATION FUELS}

Alcohol fuel utilization technology has been intensively investigated in the United States and a number of foreign countries since the early 1970s. Efforts have concentrated on methanol and ethanol, both in blends and neat or near-neat. A substantial technology base has been established to supplement that available for gasoline-fueled vehicles (15). As a result, there is no technical obstacle to the commercialization of oxygenated fuels.

Methanol and ethanol have high octane ratings (measures of the ignition quality of fuels for spark-ignition engines). To take full advantage of this feature, it is necessary to use a special engine design, with a higher compression ratio than that used for gasoline, to improve thermal efficiency and power. These factors, coupled with competitive costs of methanol, make methanol the choice of automobile companies to replace gasoline. The high compression ratios and other design features used for fuel alcohol (neat or nearly so) are essentially the same for both fuel ethanol and fuel methanol. Thus the same manufacturing run could make vehicles for both fuels (if that was the strategy) with only minor factory differences for metering somewhat different quantities of fuel into the engine cylinders (16). Alcohol vehicles dominate automobile manufacture in Brazil, where nearly one third of the 10 million automobiles run on hydrated ethanol (192 proof, 96\%). However, ethanol is too expensive in the United States to be used neat or near-neat now or in the forseeable future. More than 1000 methanol vehicles are being used in experimental commercial operation in the United States. Two generations of US vehicle designs (including two batches by different manuf acturers made on factory production lines in 1981 and 1983) are a part of this total. However, the transition to alcohol fuels in the United States is seriously hindered by the enormous problem of changing over the huge infrastructure that supports the 100 million gasoline vehicles in use. Although both methanol vehicles and fuels can be made, there is no incentive for either without existence of the other. Some sort of government involvement will probably be required to overcome this chicken-or-egg situation if alcohol fuels are deemed desirable.

Methanol, ethanol, or other higher-order oxygenated hydrocarbons can also be mixed with commercial gasoline, usually called blends; this has been done since 1971, when tertiary butyl alcohol (TBA) was introduced owing to its availability as a chemical industry by-product. However, the primary impact came in 1979, with the ad hoc addition of one part ethanol to nine parts 
unleaded gasoline (often called Gasohol ${ }^{\mathrm{TM}}{ }^{2}$ ) in Illinois, as an outgrowth of efforts by the Nebraska Gasohol Commission (17) to find an expanded market for corn. Gasohol sales started with independent service stations and expanded to sales by co-ops and then by several major petroleum companies. Financial incentives adopted by the federal and state governments added impetus and thereby ensured success. A key factor in acceptance by the motorist was that no changes in or adjustments to the vehicle are required. Addition of ethanol (like that of other oxygenates) has the benefit of increasing octane and extending supplies of petroleum. Activities first by Sun Oil and then by Atlantic Richfield (ARCO) raised interest in methanol as an octane-enhancing blending agent.

The use of a methanol derivative, methyl tertiary butyl ether (MTBE), as an octane-boosting agent began in Europe, and spread to the United States in the wake of concerns about the future availability of octane-blending agents during the period of increasing environmental opposition to lead-containing chemicals.

Characteristics of methanol-gasoline blends are sufficiently different from those of ethanol and gasohol that it is not practical to blend the former in the field, and it was not until 1981 that ARCO started the first refinery blending, including modifying the gasoline so that the composite final product would meet customary gasoline fuel specifications.

The advantages and disadvantages of alcohols as fuel are a result of their physical, chemical, and combustion characteristics. Methanol, of all the oxygenates, deviates the furthest from gasoline. Ethanol's characteristics generally fall between those of methanol and gasoline, and those of other oxygenates fall between those of ethanol and gasoline in ascending order of molecular weight (decreasing oxygen content), constituting a family of curves.

Generally, mixing alcohols with gasoline gives characteristic differences roughly proportional to the alcohol concentration, though not all effects are linear. The exceptions are vapor pressure and water tolerance. Characteristics of neat alcohols in relation to gasoline are as follows (18):

1. Methanol has an energy density per unit volume about half (48\%) that of gasoline, and fuel economy basically relates to this characteristic. Ethanol contains about two thirds (66\%) the energy of an equal unit of gasoline.

2. Methanol requires more than seven times the heat needed for gasoline to vaporize a unit of energy. This results in a cooler charge admitted to the combustion chamber, yielding more charge energy (increased volumetric efficiency), greater power output, and increased thermal efficiency (about 6\%

\footnotetext{
${ }^{2} \mathrm{TM}$ trademark of the Nebraska Agriculture Industrial Products Commission (more popularly called the Nebraska Gasohol Commission), but generally adopted as a generic name.
} 
higher relative to gasoline). Ethanol requires about four times the heat needed for gasoline, and has about $4 \%$ greater thermal efficiency.

3. Methanol burns cooler than gasoline. Since the formation of oxides of nitrogen $\left(\mathrm{NO}_{\mathrm{x}}\right)$ is temperature-dependent, $\mathrm{NO}_{\mathrm{x}}$ emissions are reduced by about half, all other factors being equal.

4. Unburned fuel emissions from methanol consist of methanol and partial combustion products. The emissions of greatest concern are aldehydes, though these are not believed to be detrimental at the low levels produced. Aldehydes are mainly formaldehyde from methanol and acetaldehyde from ethanol.

5. Methanol corrodes certain fuel system metals, notably zinc, lead, aluminum, and magnesium. The rate of corrosion is highly dependent on methanol purity and water content. Ethanol is more benign but also attacks magnesium and aluminum.

6. Exposure to methanol results in different swelling, shrinking, and ductility of some elastomers. This effect is appreciably less with ethanol.

7. Alcohols burn cleanly, and combustion chamber deposits are minimal.

With regard to methanol-gasoline blends, the following additional factors are pertinent (18):

1. Since methanol is polar and gasoline is not, the vapor pressure of a mixture increases appreciably (about 3 psi) with even a small amount of methanol. The effect of ethanol is about one third as great. Other oxygenates have lesser effects, and their use with methanol partially offsets the effect. Evaporative emissions increase with increasing vapor pressure, as does the propensity for vapor lock.

2. A methanol-gasoline mixture will form two separate liquid layers in the presence of a small amount of water. Ethanol-gasoline mixtures can accommodate about four times as much water. Susceptibility to separation diminishes with an increase in (a) alcohol concentration, $(b)$ gasoline aromaticity, and $(c)$ temperature. Addition of $\mathrm{C}_{3}-\mathrm{C}_{9}$ oxygenates, singly or in combination, also reduces the likelihood of phase separation. Such ingredients are called cosolvents. Ethanol can be used wholly or in part as a cosolvent for a methanol-gasoline mixture where only limited effects are required.

3. Various operating characteristics and emissions are influenced by the fuel : air ratio of the charge brought into the combustion chamber. The oxygen in methanol (and other oxygenated hydrocarbons) changes this ratio (as compared to neat gasoline) when a fuel blend is used, unless a closed loop electronic fuel control system is used (equivalent to mechanically readjusting the carburetor to a leaner fuel mixture).

4. Enleanment (increased air: fuel ratio) typically results in reduced emissions of unburned fuel (hydrocarbons) and carbon monoxide. $\mathrm{NO}_{\mathrm{x}}$ emissions 
are often increased, though they may be reduced or remain the same. The aldehyde fraction of the unburned fuel increases.

5. Enleanment results in reduced power and increased thermal efficiency.

6. The improved thermal efficiency owing to the combination of charge cooling and enleanment partly off sets the reduced energy density of the fuel, so perhaps one fourth to one third of the fuel economy reduction due to the low energy density is recovered.

7. Drivability (a measure of the vehicle response to driver accelerator control) is reduced with fuel enleanment. Prior to the use of alcohol blends, experts felt that enleanment beyond $2 \mathrm{wt} \%$ oxygen would not be acceptable to motorists. Experience with ethanol-gasoline blends (gasohol) and then methanol-gasoline blends has shown that drivability with $31 / 2$ wt $\%$ oxygen is generally acceptable with existing vehicles, but the dctcrioration is rapid and excessive at higher oxygen levels. Adjustment of the fuel preparation system to accommodate more alcohol will result in deteriorated performance when the engine is run on gasoline.

8. Following minor materials changes, several auto manufacturers have included under warranty provisions the use of $5 \%$ methanol (with appropriate cosolvents and additives) in a blend.

Gasohol is generally made by simply adding an appropriate amount of ethanol to gasoline, of ten called splash blending. Until 1985, conventional unleaded gasoline was used as the gasoline component. Following the Environmental Protection Agency's (EPA) requirement to reduce lead content in regular gasoline, high-octane hydrocarbon components took on greater value, and several refiners started to supply suboctane gasoline for purposes of adding ethanol. This results in a final product with characteristics much like those of straight gasoline, except for volatility and oxygen content.

Under provisions of the Clean Air Act, the EPA must determine that use of a fuel other than gasoline will not degrade air quality before that fuel can be marketed. This requirement implies also that use of the fuel will not cause abnormal deterioration of engine performance or emissions control equipment even over extended periods of operation. Prospective fuel suppliers must submit substantiating data for EPA evaluation. Approval is generally in the form of a waiver to requirements of a specific section, 211(f), of the Act. Waivers to date are listed in Table 1. Also, any alcohol may be used in gasoline provided the resulting fuel does not contain more than $2 \mathrm{wt} \%$ oxygen, under a ruling that such fuels are "substantially similar" to gasoline marketed at the time of passage of the Act.

When $10 \%$ ethanol is added to regular gasoline, the octane posted at the pump is increased by about two numbers, to about midway between the octane ratings of regular and premium grades. This increase is of benefit only to those vehicles in which the engines knock or ping (typically most evident 
Table 1 Generalized oxygenated fuels allowed by EPA

\begin{tabular}{|c|c|}
\hline Oxygenate & Max. vol \% \\
\hline Methyl-t-butyl ether (MTBE) ${ }^{\mathrm{a}}$ & 11 \\
\hline Gasoline-grade tertiary butyl alcohol (GTBA) ${ }^{a}$ & 16 \\
\hline Isopropanol $^{\mathrm{a}}$ & 7 \\
\hline Iso-, secondary, or normal butanol ${ }^{\mathrm{a}}$ & 9 \\
\hline Ethanol (EtOH) & 10 \\
\hline Methanol $(\mathrm{MeOH})$ with GTBA (up to $1: 1$ ) & 9.5 \\
\hline \multicolumn{2}{|l|}{$\mathrm{MeOH}$ with cosolvents (EtOH, propanol, butanols) } \\
\hline $1: 1+$ corrosion inhibitor & 7.5 \\
\hline
\end{tabular}

during acceleration) or tend to keep running after the ignition is turned off. There is no fuel economy benefit to an existing vehicle from the use of a higher-octane fuel. Methanol provides similar octane benefits, as do several other oxygenates such as TBA and MTBE.

Water is an undesirable ingredient in motor fuels. Circumstances and practices generally permit delivery of water-free gasoline. However, water is absorbed by alcohols, so that control is more difficult. Some pipeline systems cannot protect against water pickup and therefore cannot be used to transport blends. However, proper care and housekeeping by fuel suppliers can ensure a trouble-free alcohol-gasoline blend.

At equivalent air: fuel settings, gasohol or methanol-gasoline blends have no significant advantages or disadvantages in fuel economy or exhaust emissions over gasoline. However, differences in strategies to achieve vehicle compliance with emissions regulations, driver operating techniques, traffic and road conditions, and use of vehicles may result in fuel economy differences of as much as $\pm 5 \%$ between these blends and gasoline. For example, many recent model vehicles use control mechanisms that tend to keep the fuel : air ratio constant at the best operating point for use of so-called threeway (combination of oxidation and reduction) catalysts. These mechanisms overcome the enleanment aspect of blends once they are activated, usually after engine warm-up, resulting in essentially no differences between the blends and straight gasoline in use, other than reduced fuel economy with the blends. Evaporative emissions can be higher in existing vehicles using blends if the blends have higher vapor pressure and altered distillation characteristics. Blends formulated to the same distillation characteristics as gasoline have very similar evaporative emissions. Also, charcoal canisters work well with blends, and corrective actions to accommodate modified fuel characteristics are likely possible.

Most US experimental effort now focuses on fuel methanol consisting of 
about $85 \%$ methanol and $15 \%$ light hydrocarbons, called fuel methanol or more specifically M85 (19). The hydrocarbons aid cold starting, add flame colorant to the methanol, and discourage oral ingestion of the toxic fuel.

Engines specifically designed to operate on fuel alcohol typically feature high compression ratios (11 to 12), resulting in increased power and high performance. They also result in about $10 \%$ better fuel economy, so that only 1.8 gallons of methanol (rather than 2) are required to replace a gallon of gasoline. Emissions are reduced substantially, except for those of aldehydes. The oxidation catalyst, required to manage these, also reduces the emission of other unbumed fuel constitutents. Materials exposed to the fuel have been appreciably changed. The fuel mixture preparation systems have also been redesigned to provide appropriate metering. Maximum heating of the fuel charge is usually provided. Cold starting techniques, if provided, usually involve a second fuel such as gasoline or propane, as is the case in Brazil (20). It is necessary to resolve problems in engine starting below $5^{\circ} \mathrm{F}$ (down to $-20^{\circ} \mathrm{F}$ ) on a methanol-based fuel without infusion of added fuel components before serious consideration can be given to methanol commercialization in North America, and experimental work on this problem is being conducted (21). Engines operating on fuel methanol suffer from abnormal wear during the warm-up phase, caused by formation and condensation of intermediate chemical species, such as formic acid and hydrogen peroxide, which penetrate the oil film on the cylinder walls (22). Although some methanol-fueled vehicles have operated reliably for more than 100,000 miles, some short-trip operations have resulted in poor durability. Crankcase lubricating oils that overcome this are under development and/or evaluation by Exxon, the Standard Oil Company (Ohio), Conoco, and Lubrizol, and much progress has been made (23).

Assessments made in the early 1970s projected the possibility of a $25-30 \%$ increase in fuel economy in a methanol vehicle as compared to its gasoline counterpart, with roughly equal contributions from $(a)$ increased thermal efficiency including that from a higher compression ratio, $(b)$ elimination of special emissions provisions, and $(c)$ lean operation. Concems about aldehyde emissions have led to retention of the exhaust catalyst, so only part of the emissions gains are practical. It therefore appears that $15-20 \%$ improvement over gasoline operation would be the best that might be expected from a practicable approach.

In researching various alcohol-gasoline mixtures, concentrations of up to $30 \%$ alcohol were investigated (24). Extensive field trials of $15 \%$ methanol were made in West Germany, and of $20 \%$ methanol in Sweden. It was generally felt that concentrations greater than these offered little benefit because substantial engine changes were required, and once this occurred it was best to go to an optimized system using neat or fuel alcohol. However, 
isolated assessment made first in West Germany and then the United States showed that optimization of a mixed (methanol-gasoline) system suggests use of an intermediate methanol concentration (50-70\%). This concentration would permit use of $10: 1$ or $11: 1$ compression ratios, higher than those presently used for gasoline, and give the lowest-cost fuel when methanol and gasoline are equally priced based on energy content (25). In a vehicle with an engine control system designed to optimally use either the alcohol blend or a premium gasoline, this option would offer motorists convenience in the early stages of fuel alcohol introduction, before distribution is widespread. Electronic control systems have been demonstrated that permit such fuel interchangeability, and one system, called flexible-fuel, includes an optical (refractive index) detector that determines the methanol concentration in the fuel and appropriately adjusts the engine control system (26). At least one other approach, using a capacitive sensor, is being investigated. These concepts, and their combination, came to limited serious attention only in about 1985.

Based on ignition characteristics, alcohols are unattractive diesel fuels. However, ways to make them suitable for diesel engine use have been widely investigated, because of $(a)$ national strategy considerations in countries without oil resources and $(b)$ emissions concerns related to diesel engines. Reduction of exhaust emissions, particularly oxides of nitrogen and particulates, is a major benefit. There are several technical approaches involving methanol concentrations, methods for igniting the methanol, and the convenience of adapting specific engine designs. If the combustion environment is hot enough, compression ignition will occur, but this temperature is hard to control over the speed and load range. However, a popular two-cycle bus engine has been modified for methanol and used in a number of experimental urban buses (27). Active ignition systems (spark or glow plug), dual-fuel (diesel pilot, methanol power) systems, and chemically spiked (cetaneenhanced) alcohol make up the other neat or near-neat approaches. Techniques for use of alcohol-diesel blends include chemically or mechanically emulsifying the combination, and ingesting (fumigating) the alcohol into the engine along with the air (using injection of small amounts of diesel fuel for pilot ignition). Techniques for use of chemical additives require appreciable quantities (e.g. 5-10\%) of compounds that are typically expensive and that may increase exhaust emissions. The viability of mechanical systems depends on the convenience and cost of physical changes as well as on operational factors.

The technologies for all such uses are known, but are in the early stages of design application, with only small numbers of vehicles operating experimentally. However, there is great interest in the use of neat methanol in urban buses because of the air quality benefits. A number of small ex- 
perimental fleets are now operating with promising results. The present diesel technical approaches, like those now used for gasoline substitution, are for introductory stages only. Once the markets develop, truly optimized engine designs will appear. An optimized fuel alcohol engine will be different from both the gasoline and diesel engines used today (16). In essence, it will be a high-compression (compared to gasoline), lean-combustion engine incorporating an active ignition system; akin to a direct-injection, stratifiedcharge (DISC) engine.

\section{MANUFACTURE}

Methanol is manufactured worldwide from synthesis gas, a mixture of hydrogen, carbon monoxide, and carbon dioxide that can be produced from a variety of carbonaceous materials, including natural gas (methane), petroleum liquids, and tars, or solids such as coal or biomass.

Figure 1 shows the sequence of steps by which coal is first converted to synthesis gas (gasification), which is then purified and has its $\mathrm{H}_{2}: \mathrm{CO}$ ratio adjusted (shift conversion) to that required for methanol formation, at which point it is reacted (synthesis) over a catalyst at elevated temperature and pressure to form methanol. Alternatively, using a different catalyst, a range of hydrocarbons including gasoline can be manufactured from synthesis gas (Fischer-Tropsch synthesis), as is done in South Africa.

Present manufacture of methanol is almost exclusively from natural gas, which requires less capital expenditure than manufacture from coal. However, coal is regarded as the long-term source of synthesis gas because of its large supply and wide distribution. In part to prepare for the future, Tennessee Eastman in 1983 constructed a methanol plant in Tennessee in which synthesis gas is made from lignite coal using a Texaco gasifier. Also, a methanolfrom-lignite demonstration plant using the Winkler gasification process has been announced in West Germany (28).

The manufacture of synthesis gas by coal gasification represents a major cost in methanol manufacture. Incremental improvements are significant and have been described (29-31).

For many years the standard catalyst for conversion of synthesis gas to methanol was zinc oxide in combination with alumina or chromia. The reaction was carried out at 3000 to $6000 \mathrm{psi}$ and $350^{\circ} \mathrm{C}$. However, beginning in the 1970s Imperial Chemical Industries, Ltd. introduced a coppercontaining catalyst based on zinc oxide that permits synthesis to be carried out at pressures of $1500 \mathrm{psi}$ or lower and $250^{\circ} \mathrm{C}$. Modern methanol plants now use this type of catalyst $(32,33)$.

Mixtures of alcohols, such as $\mathrm{C}_{1}-\mathrm{C}_{4}$, are manufactured from synthesis 


\section{PROCESS STEPS IN INDIRECT COAL LIQUEFACTION}

\section{Monufocture of}

(1) Methonol (2) MTG Gosoline (3) Fischer-Tropsch Fuels

Numbers ore entholpy chonge,

$\Delta H, \mathrm{Kcol} / \mathrm{g}$-mole., - indicotes exothermic heof of reoction.

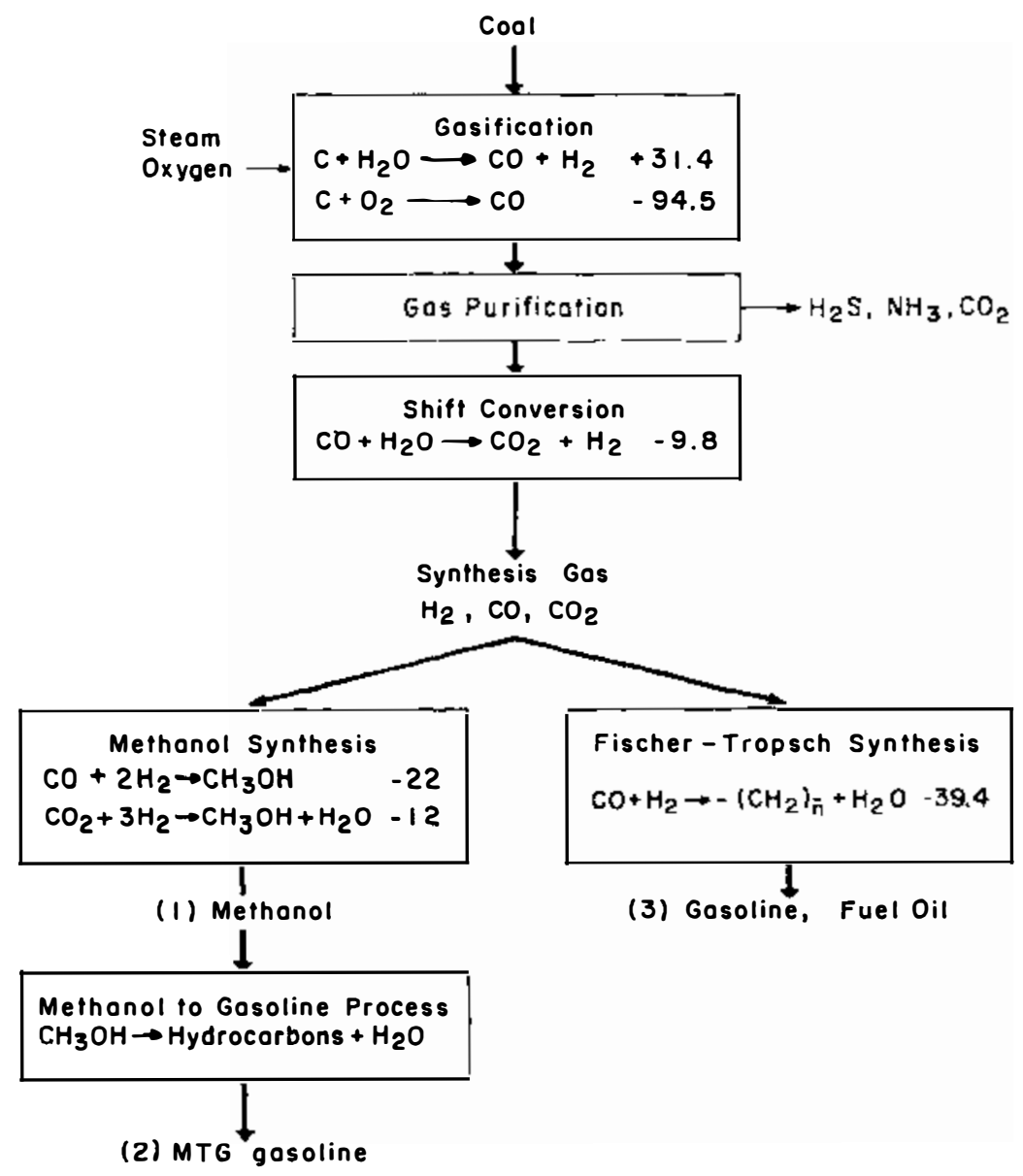

Figure 1 Process steps in indirect coal liquefaction. 
gas in the same way as methanol, but with changes in catalyst composition and operating condition changes (discussed later).

\section{ECONOMICS}

\section{Manufacture}

Although there are wide ranges in raw materials costs, methods of calculating process economics, and-for coal-process complexity, it is possible to establish basic economic facts by simplified calculations $(34,35)$. At present, natural gas prices around the world vary from about $\$ 0.5$ to $\$ 5.0 / \mathrm{MBtu}$ (million Btu), a tenfold ratio. The thermal efficiency in going from natural gas to pure methanol is about $60 \%$. Thus, the cost for feed and fuel is from about $\$ 0.8$ to $\$ 8 / \mathrm{MBtu}$ of product methanol for the range of gas prices cited. Capital charges are higher in areas with low gas costs (mainly remote or otherwise industrially underdeveloped areas) because of normally higher investment required there. Representative capital costs in areas of low and high gas prices are respectively $\$ 35$ and $\$ 15$ per annual MBtu of methanol produced. (The figure $\$ 15$ corresponds to an investment of about $\$ 5000$ per daily MBtu, equivalent to 15 gallons of methanol a day). Table 2 shows the approximate selling price of methanol given certain stated assumptions.

Any change in capital costs or in tax or profit can be seen to affect the selling price, since they represent so large a fraction of the selling price. Recently, the actual price of methanol on the US Gulf Coast has been as low as $40 \notin /$ gallon (corresponding to $\$ 6.2 / \mathrm{MBtu}$ ), reflecting the oversupply situation and the price of gas (less than $\$ 5 / \mathrm{MBtu}$ ). For comparison, the price of crude oil at $\$ 15 / \mathrm{barrel}$ is $\$ 2.6 / \mathrm{MBtu}$; gasoline made from it costs about $\$ 3.8 / \mathrm{MBtu}$, or $50 \varnothing /$ gallon (without tax). These figures indicate why methanol

Table 2 Approximate selling price of methanol at full capital retum $^{\mathrm{a}}(34)$

\begin{tabular}{lcc}
\hline \hline & \multicolumn{2}{c}{$\$ /$ MBtu } \\
\cline { 2 - 3 } & Low gas cost & High gas cost \\
\hline Feed and fuel & 0.8 & 8.0 \\
Other plant costs & 1.5 & 1.2 \\
Capital charge & 10.5 & 4.5 \\
$\quad$ Total & 12.8 & 13.7 \\
\$/US gallon & 0.83 & 0.89 \\
\hline
\end{tabular}

\footnotetext{
${ }^{a}$ Using a uniform capital charge of $30 \%$ to cover $10 \%$ federal taxes, $10 \%$ profit after taxes, $5 \%$ depreciation, $3 \%$ maintenance charges, and $2 \%$ insurance and local taxes. Based on new natural gas methanol plants on stream in 1986.

${ }^{\mathrm{b}}(0.065 \times \$ / \mathrm{MBtu}=\notin /$ gallon methanol $)$
} 
Table 3 Cost estimates of synthetic fuels from coala $^{\text {a }}(37)$

\begin{tabular}{lc}
\hline Product/process & \\
\hline Direct liqucfaction & \\
gasoline and distillates & \\
Indirect liquefaction & $5.81-5.59$ \\
Fischer-Tropsch & 4.54 \\
Methanol & 4.91 \\
Methanol-to-gasoline & \\
\hline a The comparative economics, rather than the absolute \\
numbers in this 1979 study, are significant.
\end{tabular}

is at an economic disadvantage compared to petroleum-derived fuels and why it is not widely used today as a transportation fuel except for minor quantities used in gasoline blends, justified mainly on an octane-boosting basis.

The projected costs of coal-based methanol are somewhat higher than those of methanol from gas because of higher capital costs, even though coal can be less expensive than gas on a heating value basis. Many economic evaluations of the costs of synfuels manufacture from coal have been carried out (36-39). See Table 3 for the results of one study.

A recent study (39) based on 1984 conditions concluded that methanol from coal is approaching competitiveness with methanol from natural gas, provided that favorable financing (75/25 debt/equity) and loan guarantees can be obtained, and that the price of gas is above $\$ 4 / \mathrm{MBtu}$.

A current review (40) of which oxygenates will fill the octane gap indicates clearly that methanol is the least expensive option.

In summary, it emerges that of all synthetic transportation fuels, methanol is cheapest on a Btu basis. However, methanol is at prcsent more expensive than gasoline from low-priced petroleum.

The arguments for coal-based methanol are that the raw material costs are low, that once the plant is built the required methanol price will in time be competitive with rising petroleum prices, and that the resource base is large and is within the United States. Economics of methanol are favorable compared to those of other coal-based substitutes for gasoline.

If markets are to develop they will be based on the conviction that in time, taking into account any performance advantages that methanol offers, the price will be lower than those of petroleum fuels. In the early years this price advantage will be due to the low price of plentiful natural gas in many areas, and in later years to the emergence of large-scale coal-based plants in those countries with low-cost coal (34).

It should be pointed out that synfuels are more economically attractive 
when the real values of imported oil are considered. Lee (41) made the important distinction between the apparent cost of imported crude oil and the additional cost or intangible effects on the economy caused by importation. It was claimed that if the United States reduced oil imports by 500,000 BPD there would be an indirect or external benefit to the economy of $\$ 36 /$ barrel (1980 dollars) that should be added to the direct benefit, i.e. the cost of imported oil. The external benefits are made up of effects on oil price, inflation, employment, and security.

A further consideration in determining economics is that it is the whole system that needs to be evaluated. Presently, the system consists of five major components: (a) raw materials, $(b)$ conversion, $(c)$ refining, $(d)$ distribution, and $(e)$ engine use. Frequently, economics in engine use are not considered. More specifically, if methanol is used in optimized high-compression engines and produces $20 \%$ extra efficiency (in miles per Btu), then this efficiency needs to be taken into account. Engines have been developed to take advantage of the high-octane combustion characteristics of alcohol fuels.

\section{Alcohol Distribution}

Chemical grade methanol and fuel grade ethanol are shipped worldwide, incurring nominal shipping costs as evidenced by bulk imports of the former selling for less than $\$ 0.40 /$ gallon in 1986 . Oxygenated blends have been transported by pipeline and tank truck for several years, here and abroad. Precautions need to be taken to keep the system dry. Experience has shown little water pickup from the atmosphere, though desiccants can be and have been used in practice.

Following tests in 1982, Atlantic Richfield (ARCO) pipelined over 35 million barrels of Oxinol ${ }^{\mathrm{TM}}$ blends in its Pennsylvania-New York pipeline, serving over 20 terminals from Philadelphia to Pittsburgh, Syracuse, Rochester, and Tonawanda. Several companies have stated that they will pipeline oxygenated products, and it has been noted that common carriers will handle such products in a routine manner so long as there are identified shippers and receivers (42). Celanese Canada has successfully moved 4000 tons of methanol by pipeline over a mountainous 750-mile route from Edmonton to Vancouver with acceptable results, and such movement could cut rail freight cost up to $50 \%$ and truck delivery costs even more.

Compatible tanks for blends and fuel-grade oxygenates are available, and numerous existing tanks have been conditioned for such fuels. Dispensing equipment is similarly available and in use. Thousands of US service stations are equipped to handle blends. Equipment compatible with near-neat ethanol is widely used in Brazil to fuel the more than three million vehicles there operating on E96 (4\% water). About 30 fuel methanol dispensing systems are in use in the United States, some dating back to 1981 and earlier. 
Many underground petroleum tanks are being replaced, probably at a more rapid rate recently, owing to environmental concerns and a long history of tank leakage that is no longer acceptable. Indeed, California and possibly other states now require double tanks to permit eventual replacement without ground contamination once the integrity of the container is violated. Thus there is no basic problem in converting the system. Since use of blends can result in phase separation, it is not illogical that new tanks be compatible with both gasoline and alcohols, but it is not known if this is occurring.

The main issue related to storage and distribution is that of perceiving and/or achieving a threshold market. To achieve competitive energy pricing, it is necessary to move large quantities of fuel by barge or pipeline in a manner similar to that for gasoline. Blends with higher-order alcohols and ethers have entered commercial shipments, and ARCO distributed refineryblended methanol-gasoline by pipeline (before selling its Philadelphia refinery). However, the market for ethanol has been insufficient to warrant refinery blending and bulk shipment. Thus ethanol has typically been shipped by rail or tank truck, and its use is limited geographically. An analysis of added shipping costs for ethanol-gasoline blends showed that for use of 2.5 billion gallons of ethanol in 1995 and 4 billion gallons in 2000 the cost of the fuel would be increased by $0.5-1.9 \notin /$ gallon. This analysis is based on the assumption of moving ethanol by truck or rail to the blending terminal and the final fuel by truck to the retail outlet (43).

In California, transporting methanol by ship instead of surface hauling from Texas would reduce costs of fuel methanol by 15-20ф/gallon. If M85 were used in large enough quantities to ship in the manner used for gasoline, the added distribution cost would be in the range of 2.2-4.9 $₫$ /gallon. This cost would be somewhat reduced by the added efficiency of vehicle operation.

There would be appreciable cost in adapting the system. Nearly twice the number of tank trucks would be required. Equipping service stations would also be costly, though well within the investment range of major companies, especially when incrementally introduced. It has been estimated that 93,000 service stations account for $77 \%$ of all retail fuel sales, and that these could be equipped with new fueling units for $\$ 28,000$ each, based on actual experience of the California Energy Commission (44). If existing tanks were to be used, this cost would be substantially reduced since more than half of the cost is associated with tank installation. Presently about $90 \%$ of the retail tanks are made of carbon steel, which is suitable for methanol use, as are many of the fiberglass tanks that are now replacing steel tanks.

\section{TRANSITION/GOVERNMENT INTERVENTION}

Government intervention in the marketplace can play a significant role in the use of alcohol fuels. Such intervention was essential to success in Brazil, the 
only country to achieve an appreciable percentage of alcohol fuel use to date.

The US government has intervened selectively, only in the ethanol market. Incentives for use of gasohol spurred initial use and, together with state incentives, have perpetuated sales competitive with gasoline. Presently there is a waiver of $6 \notin$ of the $9 \not /$ gallon federal excise tax on gasoline where $10 \%$ ethanol from renewable resources is used. State incentives range up to $14 \phi /$ gallon, but are generally on the order of $4 \notin /$ gallon. Thus the combined incentives range from 6 to $20 \% /$ gallon of fuel or $\$ 0.60-\$ 2.00 /$ gallon of ethanol. Ethanol prices were about $\$ 1.60-\$ 1.70$ /gallon during 1985 and $\$ 0.79-\$ 1.01 /$ gallon in late 1986 . The distilling industry notes that these incentives are essential to continued ethanol fuel sales. Brazilian experience is similar, in that support is required to maintain competitive pricing. Indeed, throughout this century ethanol has often been used in gasoline, but always in times of agricultural or national problems and always at premium prices compared to gasoline.

The federal government has provided incentives for ethanol production in several pieces of legislation over the past decade, distributed through the Departments of Agriculture and Energy. These incentives have generally been in the form of loan guarantees, and have made only minor contributions to the available fuel capacity.

The government has not been involved directly in encouraging methanol blends through tax actions that would alter competitive economics. The economic benefits of methanol use in gasoline disappeared with low oil prices in 1986. However, before then commercial competition arose between octane-poor and octane-rich refiners and marketers, with some of the former promoting methanol-gasoline blends and some of the latter fighting off competition of these lower-priced oxygenates. Public arguments between competitors included information negative to methanol and conflicting to motorists, thereby appreciably hindering market development. Had this not occurred and oil prices held steady, government (EPA) phase-down of lead in gasoline might have spurred alcohol use appreciably. Another factor during this same period was an EPA ruling allowing the use of mixed methanolethanol blends (the so-called Dupont waiver) that brought in a new factor of volatility control (now removed), which largely negated commercial interest in this composition. California has not permitted use of methanol blends, although the legislature has provided a window for sizable industry field trials to permit demonstration of effective means of controlling evaporative emissions. This demonstration is not yet concluded.

Considerable controversy has developed between US fuel ethanol producers and those involved in importing such products from foreign countries. Tax incentives for agricultural ethanol were probably intended for only domestic products, but also accrued to foreign products. Tariffs were levied on imports to offset these incentives. These tariffs were then waived for some Caribbean 
countries as part of a program of economic aid. This resulted in great controversy over both the waiver and various schemes for qualifying ethanolcontaining products exported to the United States.

Fuel ethanol holds no interest for the automotive industry because of poor economics. In general, the industry view is that methanol is the logical fuel of choice to augment or replace gasoline when it becomes practicable to do so. Although the automotive industry is sensitive to government involvement, the one exception is the apparent position that government must intercede if fuel methanol is to be used (45). It is the general view that industry as a whole must simultaneously move to this (or any other) new fuel.

The transition to a new fuel has long been viewed as a major obstacle, primarily because of the huge existing petroleum-oriented infrastructure and the so-called chicken-or-egg dilemma wherein there is no demand for fuel methanol because there are no vehicles to use it and no demand for vehicles because there is no fuel infrastructure. However, a relatively new concept has been proven in vehicles that provides normal operation on gasoline, yet uses methanol effectively when it is available. This concept uses a device in the fuel line that detects the fuel composition and takes advantage of recent incorporation in vehicles of fuel injectors and electronic fuel control systems (26). The system permits optimal results at a selected compression ratio whether the fuel is gasoline, methanol, or any combination thereof. Thus, most benefits of methanol are obtained. Also, only a single fuel tank is required, and motorists are not confined to areas of methanol availability. The cost differential is small. A number of experimental vehicles now incorporate this so-called 'flexible-fuel system,' and variations in devices and systems are under development. Although some methanol benefits are partially sacrificed in retaining the ability to use regular gasoline, the remaining methanol advantages will encourage the operator to favor its use. For a given design, methanol use gives improved power, torque, acceleration, and energy economy compared to gasoline (46). This, coupled with the earlier noted analysis that the most favorable fuel economics are obtained when $50-70 \%$ methanol is blended with gasoline, suggests that maximum motorist benefits may accrue from an intermediate-volume methanol blend (47). This finding suggests a basis for oil company involvement rather than promoting an adversarial atmosphere between oil companies concerned with protecting existing markets and methanol-producing chemical companies seeking new markets. Federal interest in alcohol fuel use centers on fuel methanol. A subcabinet level White House task force has been active since early 1984, focusing on providing methanol with a level regulatory playing field on which it can compete with petroleum. As a result, the EPA has proposed procedures for auto industry certification of methanol-fueled vehicles for compliance with the Clean Air Act. This proposal and other items addressed are intended to remove uncertainties that otherwise exist. 
Congress has sought to encourage commercialization of methanol-fueled vehicles through two pieces of proposed legislation. One is to offer encouragement to the auto industry by discounting methanol from the formula for calculating Corporate Average Fuel Economy (CAFE). Under this requirement manufacturers must meet specified levels of fuel economy calculated on the basis of a weighted average of cars sold. The original requirement for 1985 was 27.5 miles per gallon (mpg), but public apathy toward saving oil resulted in a relaxation to $26 \mathrm{mpg}$ for 1985 and 1986 . Proposed legislation would count only the $15 \%$ gasoline component of M85 for vehicles capable of running on either gasoline or methanol. Thus an auto company could make a large, lower fuel-economy, luxury vehicle in a dual-fuel or flexible-fuel form and satisfy a market segment while gaining favorable CAFE benefits. Included in the benefits of such incentives is the fact that the existence of methanol-compatible vehicles will serve (at some vehicle population level and with appropriate economics) to break the chicken-or-egg barrier and provide for a potential alternative in the event of a petroleum supply upset (47).

Another legislative initiative, which originally supported the CAFE incentive, would require federal purchase of 20,000 methanol-fueled vehicles over a four-year period, set up an over-the-road truck demonstration of methanol use, and promote demonstration and follow-on use of methanolfueled urban buses as a way to improve air quality. This legislation was passed by the House of Representatives in late 1986 (though not by the Senate), and is expected to be pursued early in the new legislative session. As forerunners to this initiative, Congress in fiscal year 1985 charged the Departments of the Army and Energy to establish federal demonstration fleets, and these fleets are in operation at several locations. The bus provision follows on activities by the Urban Mass Transportation Administration (UMTA) and the California Energy Commission (CEC). The former includes a demonstration of three retrofitted urban buses in Jacksonville, Florida, and partial funding of methanol buses for several transit districts throughout the country. Follow-on will involve $60-100$ buses in six to eight locales. The CEC sponsored procurement of a factory-built bus from each of two manufacturers for operation in the San Francisco area, and these have operated for about three years. The greatest impetus for bus operation on methanol is the demand for clean air through reduced emissions of particulates and $\mathrm{NO}_{\mathrm{x}}$. Follow-on activities are in progress or soon will be in Seattle, Los Angeles, Riverside, California, Buffalo and Utica, New York, and New York City, with a total of 60 buses. The federal influence on buses may be greater than that on autos, because UMTA provides $80 \%$ of funding for urban transportation systems and EPA diesel engine emissions requirements for 1991 may well necessitate use of a different fuel. The Detroit Diesel division of General Motors, manufacturers of about $80 \%$ of US urban bus engines, plans to 
develop a prototype methanol-fueled diesel engine in time to permit 1991 production in place of the present diesel-fuel model (48).

An extensive proposed plan "for government intervention to replace oil imports, reduce acid rain, and revitalize our domestic economy" has been presented by two environmental experts, based on methanol vehicular fuel (44). This plan involves incentives for the several classes of participants in each activity.

Another concept, based on government involvement to prepare for fuel methanol use to supplement gasoline supplies, has also been set forth for consideration (49). This differs in that it is based on establishing a transition system for discretionary use of methanol as conditions permit or necessitate. Investment in this system would not entail unpredictable fuel price supports prior to self-sufficiency. It would provide a permanent, long-range solution to replacing petroleum, as opposed to the Strategic Petroleum Reserve, which provides for short-term relief of a petroleum shortfall at a substantial annual carrying charge.

Rationale for support of federal implementation of a managed, smooth, long-term transition to natural-gas-based-and ultimately coal-basedmethanol fuel, indicates that the risk of doing so is now less than the risk of failing to do so (50). Part of the reasoning is based on an examination by one of the authors of that work of the significant negative economic impacts of major transportation technological changes between 1840 and 1983. Each major economic recession during this period was preceded by a major technological change in either transportation equipment or fuel (50a).

\section{INDUSTRY ACTIONS}

The automotive and petroleum industries have viewed the use of alcohols quite differently. In a general way, the automotive industry viewed blends as adding an undesired cost with no offsetting benefits. This is because materials needed to be changed to those compatible with both oxygenates and gasoline, and engineering effort was required to do this. Fuel methanol is viewed as the best option to replace gasoline, because improved performance, emissions, and efficiency provide benefits to the auto manufacturers. Fuel- and neatethanol are viewed by both the automotive and petroleum industry as noncompetitive now and in the long term.

The general position of the petroleum industry on methanol is diametrically opposed to that of the auto industry. Although many companies have been transformed into broad energy resources business, the petroleum segments remain dedicated to hydrocarbon fuels from petroleum. Thus, fuel alcohols are dismissed as an unlikely option by the rank and file. However, most 
accept the potential of alcohols and other oxygenates as octane-blending agents.

Once beyond generalities, the views shift depending on business circumstances.

In any automotive and petroleum company, the number of professionals engaged in alternative fuels investigation is very limited. Planning people are aware of the subject, and some here and there, are knowledgeable in depth. In large companies, one to a dozen professionals may be immersed in the subject, but often only to keep abreast of developments. Thus, the majority see no reason to consider alternatives. The greatest impetus for alcohols comes from chemical companies presently awash in methanol or from agricultural organizations also seeking relief from economic problems or seeking a business opportunity.

With regard to blends, a number of larger petroleum companies that market in agricultural regions embraced ethanol in gasoline to satisfy their customers as long as subsidies made it practical. However, low gasoline prices resulted in some parties discontinuing ethanol blends. At least two pioneering companies were optimistic about methanol-cosolvent blends, but in view of earlier noted public controversy opted to use MTBE or other oxygenates rather than use methanol and risk fighting competitors who openly opposed use of methanol blends. The latter are primarily companies with extensive petroleum resources, abilities to make sufficient high-octane gasoline, or both. Methanol was a threat to some of these producers when crude oil was $\$ 25$ or more per barrel because the alcohol could be used to provide a lower-priced product. Since methanol characteristics differ appreciably from those of gasoline, one can use selected factors to support or oppose use as a fuel component, depending on business strategy. Low gasoline prices in 1985-86 largely squeezed methanol out of the market.

The larger US auto manufacturers have accepted the inevitability of oxygenated fuel blends and, within limits, cover such use in vehicle warranties. Others have resisted in spite of about $10 \%$ of the gasoline containing such additives. It is not clear how many parties have switched to oxygenatecompatible fuel system materials, but there has certainly been ample time to do so. However, it takes an appreciable period before long-term results of field use become known and prove to have statistical significance. It therefore appears probable that automakers' reluctance to provide written warranty coverage is a ploy to guard against unlikely but potentially costly abnormal parts deterioration. There has been a notable lack of information on field problems, suggesting that properly constituted blends work quite well and do not threaten reliability or durability. Certainly appropriate, inexpensive materials changes will ensure that oxygenated blends fully match or exceed experience with gasoline. 
Before 1980, the alcohol fuels community typically addressed the future of fuel methanol conditionally, with the phrase "if use comes into being." A Mellon Institute workshop on methanol commercialization in 1980 exhibited a general shift of attitude in that community, which then used the phrase "when commercialization occurs." Still, at this time, there is no agreement as to a logical date of introduction of fuel methanol.

The major auto producers have conducted enough R\&D to ensure that they could produce appropriate vehicles, and others are working to reach that point. US manufacturers have testified before a congressional committee that production could start in four years following a decision to do so. This time corresponds to the minimum period for the industry to move new component designs into production. Some new products require up to 10 years. One heavy-duty diesel engine manufacturer has declared the objectives of being prepared to build a methanol-fueled bus engine in 1991 as the only likely way to meet EPA emissions regulations effective at that time.

Only one major petroleum supplier has given evidence of seriously considering the use of fuel methanol, apparently as a precaution against dwindling petroleum supplies. (Production in both the North Slope and North Sea areas are expected to peak in the next few years.) Although various projections show an increasing US dependence on imports, with appreciable escalation in the 1990s, the petroleum industry and government seem very complacent.

\section{INTERNATIONAL SITUATION}

Brazil has pioneered use of ethanol, probably exhibiting the longest continuous use in blends and establishing the practicality of major use in essentially neat form. Several government actions beginning in 1931 provided for use of ethanol-gasoline blends to provide a market for surplus crops. Concentrations of up to $40 \%$ (added to $100 \%$ gasoline) were used during and shortly after World War II, and up to $30 \%$ was used seasonally in the 1960 s and early 1970s, following the sugarcane harvest.

In November 1975, Brazil established a National Alcohol Program (Proalcool) to improve the foreign exchange balance, help the sugar industry, provide employment, and reduce petroleum imports $(3,51)$. Starting without specific goals or timetable, the use of $20 \%$ ethanol on a year-around basis became an informal goal and a clear practicality by 1979 . Output of anhydrous ethanol was expanded to nearly 4 billion liters per year by 1980 .

The government operated several hundred government utility vehicles on 192 proof (called hydrated) ethanol beginning in 1977, and in 1979 entered into an agreement with the automotive companies aimed at 2.5 million vehicles of this type by 1985 . The government took responsibility for ensureing ethanol supply from new grass-roots distilleries. This responsibility re- 
quired raising the production goal to 10.7 billion liters per year by 1985 . Production of ethanol-fueled cars and motorist response started slowly, with 980 sold (1.2\% of sales) in January 1980 . Motorists' incentives were spurred by restrictions on petroleum sales following outbreak of the Iran-Iraq war in mid-1980, so that by year-end $73 \%$ of auto sales were of the neat alcohol type.

Despite the favorable start, subsequent economic and operational complications, including a spate of trouble with retrofitted vehicles, upset the market for a period, dropping neat ethanol vehicle sales to $9 \%$ of the market by mid-1981. However, adjustments by government and industry soon restored satisf action and motorist confidence. By the end of 1984, purchases of ethanol-fueled cars consistently ran well over $90 \%$ of total sales and more than 2.6 million such cars (over $25 \%$ of the total car population) were on the road by year-end 1985 .

Through increases in plantings, crop yields, and processing plants, cane production was raised from 8.3 million tonnes in 1976 to about 20 million tonnes in 1983 and distilleries from 130 at year-end 1979 to 535 by mid-1986 (52). However, considerable government investment was required, and with low oil prices in 1985-1986 criticism arose. By 1986, the government had contributed $\$ 8.2$ billion to develop the distilling industry, which then generated $\$ 2$ billion in annual sales (53). The industry argued that the program created 1.7 million new jobs and saved $\$ 9$ billion in foreign exchange. Despite the controversy, the government held firm and froze fuel prices at comparable competitive levels. Regardless, an outside review noted that ". . . the first decade (1976-1985) of the Brazilian national alcohol fuel program should be regarded as a success"(3).

Use of ethanol blends has been introduced in a number of less-developed countries with varying degrees of success. Zimbabwe has a 10-million-gallonper-year plant that provides ethanol for a $10 \%$ blend in gasoline, and has considered building another plant of that size. Costa Rica has the capacity for 2 million gallons per year. Kenya, on the other hand, had problems of an unidentified nature.

Use of methanol blends has occurred to some extent without government incentives. Small quantities have been used in the United States. West Germany and Austria moved rapidly to $3 \%$ concentrations. The former achieved about $60 \%$ market penetration within about one year, in 1985 , and was only temporarily eroded in 1986 by low-cost gasoline.

\section{HAZARDS OF ALCOHOL FUELS}

Considerable analysis and limited investigation have been conducted on the health and safety aspects of alcohol fuels $(54,55)$. These are generally more favorable to alcohols than to gasoline. Methanol hazards are more pronounced 
than those of ethanol. Methanol is a toxic substance that can enter the body through ingestion, inhalation, or absorption through the skin. Ethanol can be accommodated in moderate amounts, and the effects are usually reversible. Neither is true of methanol.

The two major safety hazards associated with both methanol and gasoline fuels are fire and explosion. Methanol has a flash point higher than that of gasoline. The electrical conductivity of alcohols is higher than that of gasoline, giving less danger of ignition by static discharge. Assessments of key characteristics indicate that in open air gasoline is more hazardous than the alcohols. The situation is reversed in confined areas. The potential for methanol explosion can be minimized by adding light hydrocarbons that enrich the vapor space over the liquid in a closed container above the upper explosive limit.

Adding hydrocarbons also mitigates the hazard presented by the nearly invisible flames of neat methanol. Flame visibility in bright sunlight is provided with addition of $15 \mathrm{vol} \%$ gasoline. Buming methanol radiates less heat than burning gasoline.

The solubility of alcohols in water makes fighting alcohol fires easier than fighting gasoline fires. A fogging nozzle is recommended, to prevent spreading the fire, since methanol concentrations in water as low as $21 \%$ are still flammable. Aqueous film-forming foams are recommended when fighting alcohol-gasoline blend fires, rather than the common detergent foams.

Methanol exhibits both acute and chronic effects on the human body, and has a long history of causing serious health effects, including death. Its immediate effect is as a narcotic and inebriant. Absorption into the blood in amounts exceeding $350 \mu \mathrm{g} / \mathrm{ml}$ blood (equating to $10-25 \mathrm{ml}$ ingestion) may produce weakness, heat sensation, abdominal pain, vomiting, dyspnea, visual disruptions, reversible and irreversible blindness, and convulsions. Ethanol effects are not as serious, but ethanol is absorbed directly into the blood and is distributed almost uniformly in the body. However, the greatest effect is on the brain. Ethanol acts as a depressant on the central nervous system, and is eliminated slowly from the body. Levels exceeding $5 \mathrm{mg} / \mathrm{ml}$ blood can cause death.

Deliberate or accidental ingestion of alcohols are the primary risks associated with toxicity. Pure ethanol and methanol smell quite alike, so denaturization of both is important. Accidental ingestion can occur when siphoning by mouth, and hundreds die each year from such accidents with gasoline. Residence time of toxic methanol concentrations in the body is even longer than for ethanol, but methanol is cleared more rapidly than such hydrocarbon components as toluene or xylene. The risk of ingestion of alcohol-gasoline blends is comparable to that of gasoline. There are essentially no differences between exposures to vapors of gasoline and those of a $15 \%$ methanolgasoline blend. 
Formaldehyde and its metabolite formic acid are considered mutagenic at standard test levels of 5-100 ppm. In some cases, lower levels may cause eye irritation, respiratory discomfort, and nausea. The low levels of formaldehyde produced by gasoline-powered vehicles are not considered hazardous at this time. The moderate increase in this pollutant that would result from wide use of alcohol fuels is not considered an elevated hazard.

From these effects, the toxic effects of both methanol and ethanol are judged to be much less hazardous than those of gasoline and gasoline components. Acute exposure to gasoline through ingestion, dermal contact, or evaporative interactions with eyes, muco-cutaneous membranes, and respiratory tissues is considered more irritating, disruptive, and poisonous than that to either alcohol.

Methanol used for fuel would probably not be neat, but would include additives for odor, flame coloring, and denaturing, to provide warnings or deterrents to misuse.

The chemical industry has manufactured, stored, shipped, and used large quantities of methanol for many years, and has simultaneously protected worker's health and the environment. The experiences of this industry would need to be carried over into the extended network of refiners, wholesalers, transporters, and retailers if alcohol fuel use were to become widely used, but it is expected that this could be readily accomplished.

The potential effects of methanol use on the public are also viewed as comparable to or less than those of petroleum. However, appreciable education is in order to avoid deliberate exposure due to ignorance. Accidental or casual exposure will be much lower than for workers who handle fuel routinely.

Exposure to methanol spills and vapors at service station pumps appears to present a manageable risk of minor concern. Surface spills should not present difficult environmental problems because methanol is water soluble and easily decomposed by aerobic bacteria. The effects of methanol on underground water are regarded as less damaging than those of gasoline and oil.

Microflora and microfauna in close proximity to spills and leaks will be greatly affected. However, bacteria and fungi return in about three weeks after a spill, and higher organisms shortly thereafter. This situation contrasts with the effects of a gasoline spill, from which organisms may take several months to recover.

Air quality is of concern because the ambient ozone standard, which is the key quality factor, is violated by photooxidants for appreciable periods of high temperature in many urban areas. Many environmentalists see methanol use in vehicles as a way to appreciably improve air quality.

Combustion of neat alcohol in a reciprocating engine emits far less $\mathrm{NO}_{\mathbf{x}}$ than gasoline combustion because of the cooler burning. The amount of unburned fuel (hydrocarbons) is comparable to gasoline use, but constituents 
are not as reactive. Only formaldehyde is of special concern, since more of it is produced by alcohol-fuel engines, though the level is low. Carbon monoxide emissions are comparable, since the amount primarily depends on the air: fuel ratio rather than on fuel composition. Formaldehyde is the dominant aldehyde in motor vehicle exhaust gases, though ethanol use results in acetaldehyde emissions. Formaldehyde is an irritant to the eye, nose, throat, and upper respiratory tract. However, its odor threshold is below the health limit value, and its odor can serve as a warning for the presence of odorless carbon monoxide, which usually coexists with it at much more dangerous levels. Formaldehyde is unstable in air and decomposes rapidly, so that its effects are localized. Although there is general disagreement about the carcinogenic properties of formaldehyde, the National Cancer Institute found little evidence that it causes cancer in the occupational work forces exposed to it.

The addition of alcohols to gasoline affects the properties of the blend. Addition of ethanol or methanol results in higher percentages of fuel to be evaporated at given temperatures and greater volatility values. Of the two, methanol's effects are more dramatic. Volatility-caused increases in evaporative emissions over those with gasoline can probably be accommodated by appropriate canisters, which show no substantial difference in degradation with mileage when blends are used instead of gasoline. Thus fuel-injected systems or fuel with tailored volatility provide mechanisms for control.

\section{$X$ IMPROVED TECHNOLOGY DEVELOPMENT}

\section{Methanol Dissociation for Fuel Use}

Investigation of use of synthesis gas from methanol as an engine fuel dates back at least to 1970 , initially as a means to improved emissions and later for increasing efficiency. By steam reforming or dissociating methanol, the synthesis gas (hydrogen and carbon oxides) is made available as fuel. The heating value of the synthesis gas is greater than that of the methanol from which it was derived. Thus, by using waste exhaust heat available onboard the auto to decompose the methanol, it appears that the system efficiency can be increased; $15 \%$ when methanol is steam reformed and $20 \%$ when it is dissociated. However, the appropriate comparison is that of dissociated methanol versus liquid methanol (not gasoline), and this reduces the benefits of both approaches by $6 \%$. Furthermore, accounting for reactions on a molar basis reduces the differences by much of the remainder. Practical considerations, such as the difficulty of completely dissociating the methanol, also apply. Engine tests show that the fuel consumption benefit at the same equivalence ratio and compression ratio is only $3-7 \%$ (56).

A methanol dissociation reactor is not very proficient at handling wide 
variations in output or providing good transient response. For a vehicle system dedicated to dissociated methanol, the reactor must be sized for maximum engine power and is relatively bulky. Further, it is difficult to maintain engine performance with dissociated methanol at high loads and near stoichiometric mixtures, because of uncontrolled ignition of the hydrogen. As a result of these factors, most experimenters have migrated to a composite system using dissociated methanol and very lean mixtures at light to medium loads, and liquid methanol with lean to stoichiometric mixtures as the load increases to full output.

Tests of a vehicle system have shown fuel consumption over typical driving cycles to be $5-7 \%$ less than for liquid methanol. This finding leads to the observation that unless ways can be found to eliminate conventional emissions control equipment, of fsetting the added complexity and cost of the system, dissociated methanol cannot be considered a practical option for general application (57). Prospects are not encouraging.

\section{Coal Gasification}

Recently, significant improvements in coal gasification technology have been made and demonstrated on relatively large scales. In particular, pressurized entrained-flow gasification has been demonstrated by Texaco at the Cool Water plant at the 1000 ton per day (tpd) level (58). Also the Shell Oil Co. has completed development work and is building a $200-400$ tpd plant (59). The former uses a slurry-feed, the latter a dry-feed, system. The important facts are that the use of pressure has provided an incremental economic improvement on a large-cost item and that these systems have been tested successfully on a large scale. Other advanced gasification processes have been reviewed (60), including the British Gas/Lurgi slagging gasifier. It should also be pointed out that the modern pressurized Lurgi fixed-bed process has been in successful operation in the Great Plains, US, plant and in the South African Sasol plants. The Koppers coal gasification process has been used many years to produce synthesis gas for methanol manufacture at a South African plant.

Underground (in situ) coal gasification combines extraction and conversion to synthesis gas in a single step. In addition to continuing operation in two plants in Russia since the 1950s, considerable technological progress has been made in the United States, Europe, and the Soviet Union. This has been made possible by new capabilities in directional drilling to establish horizontal underground drill-hole patterns in the coal seams, electrolinking, hydrofracturing, and underground sensing and reaction control $(61,62)$. Extensive field trials have been carried out with industry and government support, including use of tilting coal beds not otherwise readily mineable.

Larger field trials proposed to the US Department of Energy's Clean Coal 
Program have won preliminary approval. One plan is to combine in-situ gasification with methanol manufacture (63).

The use of nuclear heat to provide for the endothermic steam-coal reaction is of special interest where, as in Germany, the cost of coal is high relative to that of nuclear energy. Helium, heated by fission in a High Temperature Gas Reactor (HTGR), would supply the heat required. Laboratory and pilot plant tests using helium heated by conventional means have processed up to $1500 \mathrm{lb}$ of coal per hour, establishing an extensive data base (29). The ability to raise the helium temperature in the HTGR to $1000^{\circ} \mathrm{C}$ would be an advantage, but is not now believed possible because of materials limitations.

The coproduction of methanol and either electricity or pipeline gas of fers substantial economic advantages. Synthesis gas can be sent from a gasifier first through a methanol converter, and unconverted gas can be burned to produce electricity (as is being considered for the Cool Water plant) or reacted to produce methane (14) as can be done at the Great Plains facility. At present the coproduction of methanol and electricity is favored, including the advantageous ability to produce methanol for electricity generation in peak demand periods (64). This approach is under active commercial consideration.

Coal gasification can be accelerated by the catalytic action of added alkali salts, particularly potassium oxide, which speeds up the coal-steam reaction greatly. Lower temperatures can then be used and hence lower and less costly pressures. The technology base has been well established (65) and an 80 tpd pilot plant proposed. The main application is for manufacture of methane from coal, but the $\mathrm{CO}+\mathrm{H}_{2}$ in the synthesis gas produced could be converted to methanol instead.

\section{Alcohol Synthesis}

Direct catalytic oxidation of methane to methanol is the objective of research in numerous laboratories. Selectivities at practical conversion levels are not yet commercially attractive (66).

With regard to methanol synthesis from synthesis gas, the use of a slurry of catalyst in a liquid medium, whose improved temperature control makes possible higher conversion per pass, is being developed. This technology is in an advanced development state; tonnage amounts have been made in a process development unit (67) and a semiworks plant proposed to be installed by the Tennessee Valley Authority (TVA). Synthesis gas from coal would be converted to methanol on a once-through basis, with unconverted gas burned to generate electricity.

Additionally, a novel liquid-catalyst system being developed offers the potential for savings (68). 


\section{Mixed Alcohols}

When methanol is blended into gasoline, it has been found important to add a higher alcohol to prevent phase separation caused by the addition of water. The direct synthesis of $\mathrm{C}_{1}-\mathrm{C}_{4}$ alcohols from synthesis gas presents an attractive way to prepare an alcohol mixture for blending that provides high-octane properties and resistance to phase separation. A very active research program is being carried out worldwide. Conventional catalysts based on copper-zinc oxide have been modified to enhance their capabilities to form mixed alcohols. It has been reported that a large pilot plant has been operating in Italy $(69,70)$. Also, the Dow Chemical Company in the United States has described a process for making mixed alcohols over a different type of catalyst containing molybdenum sulfide (71).

Additionally, a different type of catalyst has shown unusually high activity for converting synthesis gas to mixed alcohols. Consisting of a finely divided group VIII metal such as cobalt $(72,73)$, or especially a platinum group metal-rhodium, palladium, or ruthenium-supported on silica or alumina (74), these catalysts can be modified by the addition of chemical constituents such as molybdena to alter the distribution of alcohols and other oxygenates formed. It is possible to make a high proportion of $C_{2}$ oxygenates, including ethanol.

It is reported that bench scale tests to make ethanol are under way in Japan using rhodium catalysts as a part of the Japanese $C_{1}$ chemistry program (75).

Attention is also drawn to a process being offered commercially for the manufacture of ethanol from synthesis gas. The process consists of the synthesis of methanol and the addition of $\mathrm{CO}$ with formation of methyl acetate, which is hydrogenated to product ethanol and methanol that is recycled (76). Each step has been well established and is of high selectivity.

\section{RELATED TOPICS}

Other areas of technical development have the potential to improve the attractiveness of methanol as a fuel. These include converting it to a more desirable gasoline component or getting more usable energy from it. Methanol is reacted with isobutene to form MTBE. Blending MTBE into gasoline is then in one sense a method of incorporating methanol into gasoline. It is recognized that it is the avoidance of the $-\mathrm{OH}$ characteristics of the alcohol that make the ether preferable. MTBE has the advantage over methanol of better compatibility with gasoline, lower vapor pressure, less corrosiveness of traditional fuel system metals, and a relatively high octane, $\mathrm{RON}=118(77)$. MTBE is in commercial use in 13 countries, including the United States. The 
economics have dictated the use of low-cost by-product isobutene. The potential for MTBE using by-product isobutene is limited (78).

Manufacture of isobutene by dehydrogenation of isobutane has generally been considered too costly for fuel use. However, this process is now being carried out by Texas Petrochemical Co. in Houston in a butadiene plant previously shut down. Also, a plant is under construction for 1988 completion in Saudi Arabia to dehydrogenate isobutane to isobutene. Both plants use the CATAFIN $^{\mathrm{R}}$ process. In Saudi Arabia the isobutene will be reacted with methanol to produce 12,500 BPD of MTBE.

A process has been developed for converting methanol to high-octane gasoline hydrocarbons using a molecular sieve catalyst. This methanol-togasoline (MTG) process was invented by scientists at Mobil and developed jointly under the sponsorship of Mobil and the US Department of Energy (4, 79). In the MTG reaction (Figure 1) methanol is almost quantitatively converted to gasoline hydrocarbons, and energy loss is only about $4 \%$. Because of the size of the molecular sieve channels, no molecules larger than those in gasoline are formed. Also, in contrast to gasoline from the Fischer-Tropsch process, the gasoline has a very high octane rating ( $96 \mathrm{RON}$ without lead). This process has been hailed as the first new route for gasoline from coal in over 40 years.

There is, of course, a cost in processing the methanol into gasoline, indicated in Table 3. The advantage over neat methanol is that the MTG gasoline, either used directly or blended into the gasoline pool, can be used in cars without modification, and no new distribution system is required, as it would be with methanol. This process has been placed in operation is New Zealand in a plant that produces $14,000 \mathrm{BPD}$ of gasoline from methanol that is manufactured from offshore gas (80). This plant provides one third of the gasoline needed in New Zealand. Clearly, the particular circumstances, including indigenous resources, and whether the size of the auto fleet justifies domestic manufacture of special engines, greatly influence the choice between methanol and MTG.

Regarding increased energy conversion from methanol, fuel cells offer highly efficient energy conversion of the chemical energy of methanol to electricity. Fuel cells could one day be used in automobiles, as they are now used in satellites.

\section{SUMMARY}

Alcohols are moving slowly but steadily toward an important role as transportation fuels with long-term economic and national security advantages. Oxygenates now represent $1 \%$ of gasoline in the United States.

The viability of alcohols use on a large scale for transportation fuels has 
increased because of improved and demonstrated technology in engine use and fuels manufacture and because of the development of a large experience base.

Extensive engine testing and optimization have shown how reliable and improved performance can be achieved, using either blends or neat fuels, to take advantage of high-octane and clean-burning characteristics of alcohol. Alcohol-cosolvent-gasoline blend compositions have been established for best performance for various alcohol contents.

The energy-efficiency advantages of alcohols have been demonstrated in high-compression engines. Further, research on use of alcohols in diesel engines and in on-board catalytic decomposition of methanol using waste heat shows promise of even greater thermal efficiency. Diesel buses for city transportation, fueled by methanol, may be an important step toward alcohol fuel use, beginning in the early 1990s.

Less expensive, low-pressure manufacture of methanol using coppercontaining catalysts is now well established. Furthermore, research on alcohol synthesis has indicated improvements, including use of slurry reactors and new catalyst compositions capable of making mixtures of alcohols selected for optimal combinations of octane and blending properties. In addition, improved coal gasification, essential to manufacture of synthesis gas from coal, has recently been demonstrated on a commercial scale using pressurized entrained-flow systems.

An alternative method of incorporation of methanol in fuels is by chemical conversion, either $(a)$ by reaction with isobutene to form MTBE, commercial in 13 countries and growing rapidly, or $(b)$ conversion by the MTG process to high-octane gasoline, as is now done in New Zealand.

Widespread experience by the public and industry with "gasohol," containing ethanol, in the United States, and similar fuels plus neat ethanol in Brazil, has helped provide a satisfactory technology base. Government tax incentives and support of engine tests have been critical in advancing technology. In addition, the actions of EPA have opened the way for development of alcohol fuels in an environmentally acceptable manner.

With regard to health and safety effects, it is judged that both methanol and ethanol are less hazardous than gasoline and gasoline components.

In summary, at present there is no technological obstacle to commercialization of alcohols as components of transportation fuels either in blends or neat. Assessment of manufacture and performance has established methanol as the preferred synthetic transportation fuel. However, special social and political circumstances can make ethanol from biomass attractive. It is recognized that no synfuel is competitive economically with present low-priced petroleum. However, it seems clear that alcohol fuels will be needed in the not too distant future. 
Continued research and testing of improved technology for more economic manufacture and use are vital in preparing for the future, as is government support.

\section{Literature Cited}

1. Meyers, R. A., ed. 1984. Handbook of Synfuels Technology. New York: McGraw Hill

2. Marsden, S. S. 1983. Methanol as a viable energy source in today's world. Ann. Rev. Energy 8:333-54

3. Geller, H. W. 1985. Ethanol fuel from sugar cane in Brazil. Ann. Rev. Energy 10:135--64

4. Wender, I. 1986. Synthesis gas as a source of fuels and chemicals: C-1 chemistry. Ann. Rev. Energy 11:295314

5. Paul, J. K. 1978. Methanol, Technology and Application to Motor Fuels. Park Ridge, N.J.: Noyes Dev. Corp.

6. Houghton-Alico, D. 1982. Alcohol Fuels-Policies, Production, and Potential. Boulder, Colo: Westwood

7. Int. Symp. Alcohol Fuel Technol. 11976. Stockholm, Sweden, 2-1977 Wolfsburg, West Germany, 3-1979. Asilomar, United States, 4-1980. Guaruja, Brazil, 5-1982. Auckland, New Zealand, 6-1984. Ottawa, Canada, 7-1986. Paris, France

8. Alcohol Week. Box 7167, Ben Franklin Station, Washington, DC. 20044

9. Matar, S. 1982. Synfuels. Tulsa, Okla: Penn Well Books

10. Beghi, G. E., ed. 1985. Synthetic Fuels. Boston, Mass: Reidel

11. Cooper, B. R., Ellington, W. A. 1984. The Science and Technology of Coal and Coal Utilization. New York: Plenum

12. Elliott, M., ed. 1981. Chemistry of Coal Utilization. 2nd suppl. vol. New York: Wiley

13. Reed, T. B., Lerner, R. M. 1973. Methanol, a versatile fuel for immediate use. Science, 28 Dec, p. 182

14. Mills, G. A., Hamey, B. 1974. Methanol-the "new" fuel from coal. CHEMTECH, 4 Jan, p. 26

15. Status of alcohol fucl utilization technology for highway transportation: a 1981 perspective. 1982. DOE/CS/5605/-7 and 8 ( 2 vol.)

16. Nichols, R. J. 1983. Discuss. 8th Natl. Eng. Conf. I.C. Engines and Combustion. Univ. Trivandrum, India

17. Fricke, C. R. 1979. Utilization of Alternative Fuels for Transportation, pp. 155-62. Am. Inst. Aeronautics and Astronautics
18. Ecklund, E. E. 1984. A technological view of methanol/gasoline blends. The U.S. Blend Methanol Experience and Outlook. Washington, DC: Inside Washington

19. Workshop on Automotive Use of Methanol-Based Fuels. 1985. Natl. Sci. Found.

20. A Common Study on Alcohols and Alcohol Blends as Motor Fuel. 1986. Natl. Swed. Board Tech. Dev., Stockholm

21. Proc. VI Int. Symp. Alcohol Fuels. 1984. Ottawa, Canada. See Ref. 7

22. Owens, E. C., Marbach, H. W. Jr., Frame, E. A., Ryan, T. W. III. 1980. Effects of alcohol fuels on engine wear. SAE 800857

23. Methanol Workshop, June 4, 1985 at Volkswagen Res. Cent., Wolfsburg Germany, Final report

24. Adt, R. R. Jr., Chester, K. A., Harrenstein, M., Kurucz, C. N., Pappas, J., et al. 1981. Characterization of alcohol/ gasoline blends as automotive fuelperformance and emission characteristics. DOE/CS/522216-Tl

25. Moultin, D. S., Sefer, N. R., Naegeli, D. W. 1985. Properties and economics of methanol-gasoline blends with high methanol content. DOE/CE/50038-1

26. Weide, J. V. D., Wineland, R. J. 1984. Vehicle operation with variable methanol/gasoline mixtures. Proc. VI Int. Symp. Alcohol Fuels Technol., pp. 3380 to 386 , Ottawa

27. Toepal, R. R., Bennethum, J. E., Heruth, R. E. 1983. Development of Detroit Diesel Allison 6V92TA methanol fueled coach engine. SAE 837744

28. Thomas, G., Nitschke, E. 1986. Rheinbraun high-temperature Winkler (HTW) pressure process. Handbook of Refining Processes, ed. R. A. Meyers, chap. 11.1, p. 11-3. McGraw Hill

29. Hebden, D., Stroud, H. J. F. 1981. Coal gasification. See Ref. 12, p. 1599

30. Hedden, K. 1984. Coal gasification. See Ref. 10 , p. 63

31. Reimert, R. 1984. Methanol production based on synthesis gas from coal and biomass. See Ref. 10 , p. 135

32. Rojgerson, P. L. 1984. The I.C.I. lowpressure methanol process. See Ref. 1, 
chap. 2.2 , p. $2-45$

33. Supp, E., Qunkler, R. F. 1984. The Lurgi low-pressure methanol process. See Ref. 1, chap. 2.4 , p. 2-113

34. Dart, J. C., Davis, B., Glessner, A. J., McCallum, P. W., Mills, G. A., et al. 1983. Methanol fuel-technology, markets, and future prospects. Energy Progress 3(3): 127

35. Mills, G. A., Knudsen, C. W. 1979. Comparative economics of synthetic hydrocarbons sources. Proc. 10th World Pet. Congr. 3:329

36. Tepper, M., Hemming, D. F., Holmes, J. M. 1984. The cost of liquid fuels from coal. Part I. Executive summary. London: I.E.A. Coal Res. 61 pp.

37. Rogers, K. A., Hill, R. F. 1979. Coal conversion comparison. US Dept. Energy Rep. No. FE-2468-51

38. Hiller, H., Garkisch, O. L. 1980. Convert coal now. Hydrocarbon Process. 59:238

39. Salmon, R. 1986. Economics of methanol production from coal and natural gas. ORNL-6091

40. Klingebiel, W. J., Coughenour, G. E. 1986. Which oxygenates will fill the oxygenates gap? Energy Prog. 6(2):106

41. Lee, B. S. 1980. Synthetic fuels and the total cost of oil imports. Oil and Gas J. 78, Sept. 1, p. 113

42. Guetens, E. G. 1986. Comments at Methanol: An alternate fuel. ASME, Region V Tech. Conf.

43. Harold, L. W. 1981. Distribution options for alcohol fuels. Final report appendix, National Alcohol Fuels Commission, pp. 761-96

44. Gray, C. L. Jr., Alson, J. A. 1985. Moving America to Methanol. Univ. Mich. Press

45. Peterson, D. E. 1984. New automotive fuels: it's time for government action. Proc. VI lnt. Symp. Alcohol Fuels Technol., pp. 3-41 to -44. Ottawa

46. Nichols, R. J. 1986. Oral presentation at Public Affairs Forum on MethanolLegislative Issues. ASME Reg. V Tech. Conf. Methanol: An Alternative Fuel

47. Nichols, R. J., Moulton, D. S., Sefer, N., Ecklund, E. E. 1986. Options for introduction of methanol as a transportation fuel. SAE 861593

48. Bennethum, J. E. 1986. Oral presentation at Public Affairs Forum on Market Acceptance of Methanol. See Ref. 46

49. McNutt, B., Ecklund, E. E. 1986. Is there a government role in methanol market development? SAE 861571

50. Larsen, R. P., Santini, D. J. 1986. Rationale for converting the U.S. transportation system to methanol fuel. Proc.
VII Int. Symp. Alcohol Fuels. Paris

50a. Santini, D. J. 1985. Commercialization of major efficiency-enhancing vehicular engine innovations: past, present, and future macroeconomic considerations. Transp. Res. Rec. 1049:24-34

51. Rothman, H., Greenshields, R., Callé, F. R. 1983. Energy from Alcohol: The Brazilian Experience. Univ. Press of Kentucky. 181 pp.

52. Oil price fall forces Brazil to reassess its alcohol car program. 1986. Baltimore Sun. April 26

53. Riding, A. 1986. Slump in oil prices is troubling Brazil. New York Times. March 17

54. Adelman, H., D'Eiscu, P., Pefley, R. 1981. Human health, safety and the environmental consequences of use of alcohols. Final report appendix, Natl. Alcohol Fuels Comm., pp. 865-79

55. Wathne, B. M., Hov, O. 1985. Environmental Impact of Methanol Motor Vehicle Fuels. Norwegian Inst. Air Res.

56. Brinkman, N. D., Stebar, R. F. 1985. A comparison of methanol and dissociated methanol illustrating effects of fuel properties on engine efficiencyexperiments and thermo-dynamic analyses. $S A E 850217$

57. Konig, A., Ellinger, K. W., Korbel, K. 1985 . Engine operation on partially dissociated methanol. SAE 850573

58. Schlinger, W. G. 1984. The Texaco coal gasification process. See Ref. 1, chap. 3.1 , p. 3-5

59. Vogt, E. V., Weller, P. J., Vanderburgt, M. J. 1984. The Shell coal gasification process. See Ref. 1, chap. 3.2 , p. $3-27$

60. Brooks, C. T., Stroud, H. J. F., Tart, K. R. 1984. The British Gas/Lurgi slagging gasifier. See Ref. 1, chap. 3.4, p. 363

61. Bailey, A. C. 1984. Developments leading to underground gasification in Western Europe. See Ref. 10

62. Edgar, T. F., Gregg, D. W. 1981. Underground gasification of coal. See Ref. 12 , chap. 26, p. 1801

63. Sigel, M. M., James, W. M., Mason, R. Z., Gash, E. W., Barone, F. T. 1984. An economic evaluation SNG and methanol using underground coal gasification. Int. Gas Res. Conf. Washington, D.C. Sept.

64. Keller, A. 1985. The coproduction of methanol and electric power from coal. Energy Prog. 5(3):131

65. Pullen, J. R. 1984. Catalytic coal gasification. ICTTSITR IEA Coal Research. London

66. Foster, N. R. 1985. Direct catalytic 
oxidation of methane to methanol-a review. Appl. Catal. 19:1-11

67. Tsao, T.R., Rao, P. 1986. The development of the liquid phase methanol process: an update. 1Ith EPRI Contractors Conf., California. May

68. Haggin, J. 1986. Liquid-phase methanol process promises cost saving. Chem. Eng. News 64(31)

69. Paggini, A. 1986. MAS process: from research to commercialization. AIChE Paper 25b. Spring Meet.

70. Garibaldi, P. 1985. Environmental problems from synfuels production. See Ref. 10 , p. 365

71. Getting mixed alcohols from synthesis gas. 1984. Chemical Week. 135(19):28

72. Courty, P. H., Arlie, J. P., Connvers, A., Mitikenko, P. Sugier, A. 1984. Hydrocarbon Process., Nov., p. 105

73. Ohno, T., Yoshimoto, M., Asseleau, L., Courty, P. 1986. Production of $\mathrm{C}_{1}$ $\mathrm{C}_{6}$ alcohols. AlChE Paper 25e, Spring

74. Poels, E. K., Ponec, V. 1983. Forma- tion of oxygenated products from synthesis gas. Specialists Periodical Rep., The R. Soc. Chem., London

75. $\mathrm{Cl}$ chemistry plant trials operation. 1985. Jpn. Chem. Week. Aug. 22

76. Marten, J. H., Camps, J. A. Process for the production of ethanol by acetate esters. 1986. 21st State of Art Symp.: Methanol as Raw Material for Fuel and Chemicals. Marco Island, Fla.

77. Unzelman, G. H., Michalski, G. 1984. Octane Improvement Update-Refinery Processing, Antiknocks, and Oxygenates. Paper, Natl. Pet. Refiners Assoc. San Antonio, Tex. March.

78. Keller, J. L., Nakaguchi, G. M., Ware, J. C. 1978. Methanol fuel modifications for highway use. US Dept. Energy, $H C P / W$ 3683-18

79. Meisel, S. L. 1981. Philos. Trans. R. Soc. London. A300, p. 157

80. Allum, K., Turnbull, D. M. 1986. Startup of world's first gas-to-gasoline plant. Scc Ref. 76 